\title{
Loss of Chromosome 6
}

National Cancer Institute

\section{Source}

National Cancer Institute. Loss of Chromosome 6. NCI Thesaurus. Code C36504.

A cytogenic abnormality that refers to loss of all or part of chromosome 6 . 